\title{
The future is now (again)
}

\section{Denver, Colorado}

A DECADE after the United States ended its frantic spending on renewable energy research - a binge triggered by the oil crises of the 1970 s and killed by the failure of alternative energy sources to live up to their promise - renewable energy has finally come of age.

Wind power now costs as little as conventional electricity sources and is starting to see utility acceptance. Sunlight powers almost 150,000 homes in California. And corn-based ethanol can be found in eight per cent of all US transportation fuels, a figure that will soon rise when new federal emission control laws take effect.

The major difference between now and ten years ago is an increasing emphasis on the bottom line: making useful energy. Without special federal tax credits and subsidies, companies are now building renewable plants that work, not just impressive demonstrations.

The 1970 s spending frenzy proved that handing vast sums of money to industry with no strings attached is no way to make progress in research. In 1974, Congress launched a five-year, \$60-million programme to develop working solar energy demonstrations - a programme that consumed $\$ 550$ million by the end of 1981 , when it was essentially abandoned. At that time, only half of the 287 projects commissioned by the Department of En- ergy (DOE) were working. Experts had promised that solar heating systems would cost between $\$ 4$ and $\$ 8$ per square foot by 1979 ; in fact, the real costs were ten times higher - between $\$ 38$ and $\$ 77$.

In the area of wind energy, tax credits were given to companies when wind machines were installed, and actually operating the machines earned the companies little more - not a policy designed to produce practical energy supplies.

The lack of results was reflected in the funding. In 1981, the last year of massive spending, DOE's total renewables budget was $\$ 898$ million; by 1983 it had been slashed to less than one-third of that.

Now renewable energy research funding is creeping back up. This year DOE expects to spend about $\$ 270$ million on renewables - almost twice as much as in 1990. But this time, the money is going to in-house research at DOE laboratories such as the Denver-based National Renewable Energy Laboratory (NREL) and to matching grants to industry. Only companies willing to commit some of their own money to renewable energy get funding.

Lacking reliable federal incentives, research on renewable energy has focused on solid science - genetically engineered bacteria to ferment biomass, new aerodynamics for wind turbine blades, molten salts to convert sunlight into electricity.

But at the same time, researchers are also showing a new concentration on the balance books. Conversations with NREL's researchers all tend to take the same course: five minutes of science and an hour of policy. No more going for the environmental soft spot; now they argue that renewables make good business sense.

For instance, Norman Hinman runs the laboratory's biofuels programme, where researchers are using biotechnology techniques to create microorganisms that can convert what is essentially kitchen garbage ('cellulose-based biomass' for the purists) into ethanol. Sixty-five per cent of municipal waste could be used to make biofuels, Hinman says, but that will not happen until there is a change in US farm policy. "We could cover the nation's entire transportation needs on biofuels alone," Hinman says, simply by producing biomass on unused farmlands (anything that grows easily, such as grass, would work) and by using the recoverable biomass that now goes into landfills. But the government pays farmers to grow surplus corn crops, which creates a supply of cheap and easily fermentable corn for the biofuel industry, and so the industry has little incentive to re-engineer its technology to use cellulose-based waste, even if the waste is freely available and has to be disposed of anyway.

Hinman's team is working to cut the cost of cellulose-based biofuels until they

\section{The windmill gets a second wind}

WHEN one considers the windmill, that quaint low-technology fixture of family farms, "It's not exactly rocket science, is it?" is the phrase that comes to mind. Yet quietly, over the past decade, wind energy has turned out to be renewable energy's strongest contender.

A new airfoil developed by the Denver-based National Renewable Energy Laboratory of the Department of Energy (DOE) managed to boost wind turbine performance by 25 per cent singlehandedly by compensating for low winds and the muck that typically builds up on blades. Improvements in the reliability of the gear mechanisms and generators that convert the rotation of the turbine blades into electricity now keep the machines running longer without maintenance. And a new variable-speed transmission design allows turbines to use more of the wind, from breezes to gales. That alone has reduced the cost of wind energy by one-third. In the past decade, these and other technical advances have quadrupled the performance of wind turbines. New turbines can now generate electricity at a cost of around 5 cents per kilowatt hour, or about the same as coal.

Last month, an lowa-based electric utility announced that it had joined up with the private US Windpower Inc. to build a $\$ 200$-million wind farm in the Midwest United States - the country's windiest region. Expected to total as many as 800 turbines, the facility would generate at least $250 \mathrm{MW}$ of power, enough for 100,000 households. Although the sparsely populated Midwest does not

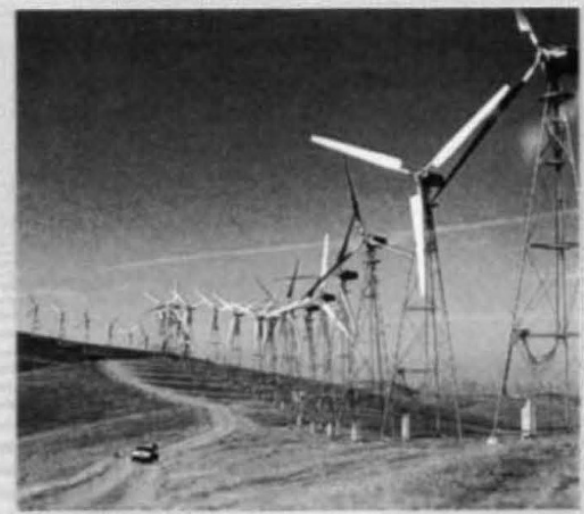

A nightmare for Don Quixote. need the extra power, the consortium partners hope to sell the electricity to neighbouring states with growing energy needs.

In California, which produces 80 per cent of the world's wind energy, windmills now generate $1,600 \mathrm{MW}$ of electricity, enough for the city of San Francisco and totalling about 1.5 per cent of the state's total consumption. The state's biggest utility, Pacific Gas and Electric, announced earlier this year that it would rely on conservation and wind energy alone to handle its increased demand over the next decade.

In Washington, too, wind is back in vogue. Total DOE wind research funding will be about $\$ 30$ million next year, twice what it was two years ago, although still less than the $\$ 50$ million that DOE was spending yearly at the peak of the renewable energy frenzy of the 1970 s. Perhaps the surest sign that wind power has finally come of age is that private industry now spends about $\$ 30$ million of its own money on wind research, without federal tax concessions, subsidies or handouts.

C.A. 
are as cheap as the alternatives. At present, biofuel producers use acids to break down wood waste so that it can be fermented into ethanol, a process that costs about $\$ 1.25$ per gallon. But NREL estimates that its bio-engineered enzymes can reduce that cost to about $\$ .60$ by the end of the decade. At that price, biofuels would be no more expensive than gasoline.

In DOE's solar energy programme, too, science must share the stage with policy and economics. It is not enough, for instance, for solar energy to be technically efficient; it must suit the needs of the electric utilities as well. Most power companies arrange their wiring so that each electric substation serves about two dozen houses. That, it turns out, is just about what a small photovoltaic (PV) facility a half-acre of solar cells - can support. Because the wiring is already in place, NREL technology analysis manager Lynn Coles says that 'grid-connected PV' may be the most painless way for utilities to begin to use solar energy. NREL, along with Pacific Gas and Electric, a California utility, and the Electric Power Research Institute, is planning a trial project.

In September, President Bush officially launched renewable energy's new future by creating NREL - a full-blown national laboratory - out of the old Solar Energy Research Institute. NREL is now starting construction on a new, \$20-million building on land donated by the state of Colorado. But perhaps the surest sign that renewable energy's doldrums are over is NREL's budget _ $\$ 125$ million, almost exactly its predecessor's peak in 1980, the last time the renewable future looked as bright.

\section{A bright light goes out}

IN the renewable-energy doldrums of the 1980 s, one company managed to keep the solar torch alive. Luz International Ltd was not only the world's largest solar energy research and production company, but by the end of the decade it was generating 95 per cent of the world's utility-scale solar electricity, sending an average of $354 \mathrm{MW}$ (enough to power 140,000 households) into the California electric grid.

Then the whole thing fell apart. Last week, Luz filed for bankruptcy. Although its nine electricity-generating facilities will remain, thanks to binding utility commitments, the construction, research and development and financing companies - Luz's future - are no more.

Ironically, the collapse came just as Luz said its solar energy technology was about to become cost-competitive with conventional energy sources, such as coal. Until it halted construction earlier this year, Luz was building the next generation of solar power plant: a facility, known as SEGS $X$, in which rows of mirrored channels would focus sunlight on pipes of oil, heating the oil, which in turn would be used to turn water into steam to drive turbines. Luz predicted that SEGS $X$, planned for completion in 1995 , would generate $80 \mathrm{MW}$ at between 6 and 6.5 cents per $\mathrm{kWh}$, somewhere between the cost of natural gas and coal, and less than nuclear plants.

What sank Luz was not bad science, technological hurdles, or bad manage- ment; it was simply politics. In contrast to the oil, gas, coal and nuclear industries, the solar industry has only one lobbyist in Washington. Every year the federal solar tax credits expire, and every year there is doubt until the last minute on whether that lobbyist will be able to get them reinstated. This year, faced with the possibility that it might not have another year of credits, Luz rushed to finish its latest solar plant in about seven and half months. The crash construction schedule put the project more than $\$ 30$ million over budget and wiped out Luz's cash reserves.

Meanwhile, in California, Luz was fighting a losing battle on another front. An error by the state's financial office had mistakenly showed that the company's property tax credits would cost California some $\$ 60$ million. Based on that assessment, the governor vetoed a bill renewing the credits. By the time the mistake was rectified (it turned out that each solar plant would actually generate about $\$ 55$ million in tax revenues for the state over its lifetime), one of the key investors in SEGS $X$ had dropped out. Other investors and banks soon withdrew as well, citing the political and financial uncertainties.

In July, Luz halted construction on SEGS $X$ and laid off most of its employees. Last week it started liquidation procedures to sell off all but the existing solar plants, which will continue to operate under private ownership.

\section{Robbing west to pay east}

\section{Bonn}

ON 22 November the Bundestag approved a 1992 budget for the German research ministry that is 9.7 per cent more than the ministry's 1991 budget. That increase is illusory, however, because with the unification of Germany, the budget must now be spread over a population that is more than 25 per cent larger than before.

The ruling coalition parties of the Christian Democrats and Liberals settled on a budget of DM9,254 million, a figure that the opposition parties rejected as insufficient. The Social Democrats had demanded a budget of at least DM10,000 million, and one Social Democrat, Emil Schnell, said during the debate on the bill that research will be among the losers in German unification.

Research minister Heinz Riesenhuber has referred to the planned spending as a "budget of solidarity" because it will trim funds in western Germany in order to establish a competitive research infrastruc- ture in the east.

Out of the DM9,254-million budget, DM1,300 million will go to pay for research in the new Länder (states), along with an extra DM300 million from the Ministry of Finance. This figure includes DM585 million to establish new institutes out of the institutes of the Academy of Sciences of the former East Germany; of that, DM416 million is allocated to setting up 'blue-list establishments', new national research laboratories and branches of western institutes.

The budget of the Max Planck Gesellschaft will be increased by 8.9 per cent to a total of DM555 million so that it can establish new institutes in eastern Germany; about 10 per cent of its total budget will flow into the east. And the budget of the Fraunhofer Gesellschaft the biggest institution of applied research in Germany - will be increased by 83.9 per cent to DM332 million, with much of the increase set aside for research in the new Länder.

When the budget is broken down by research area, space research and technology shows one of the largest increases for the coming year. The space budget will increase by 12.8 per cent, to DM1,737 million, despite the fact that Riesenhuber has retreated from some of Germany's obligations to international space collaborations (see Nature 354, 256; 28 November 1991).

Some areas did not fare so well. Particularly hard hit are the 13 national laboratories in the west, which depend on the research ministry for 90 per cent of their budgets and get the rest from the Länder. Riesenhuber froze the budget for these laboratories at the 1991 level - DM2,313 million - until the end of 1994. Cuts were made in coal research and technology (down 16 per cent, to DM122.7 million) and nuclear power (down 4 per cent to DM566.9 million). Although researchers in the east may be pleased, it remains to be seen whether research in the west will be able to thrive under these conditions.

Barbara Bachtler 